\title{
Assédio moral na relação de trabalho: da proteção ao empregado no Brasil contra as revistas pessoais
}

\author{
Taíla Mussi ${ }^{1}$ \\ Lourival José de Oliveira ${ }^{2}$
}

\begin{abstract}
Resumo
Pesquisou-se sobre a deflagração do assédio moral no cenário das relações empregatícias, fenômeno que se revela como um comportamento depreciativo do caráter humano, que atenta contra a integridade física e psíquica do trabalhador, bem como a possibilidade de realização das revistas pessoais dos empregados por seus empregadores, como situação não prevista e delineada pelo ordenamento jurídico brasileiro. Examinou-se, assim, a possibilidade patronal de vasculhar e inspecionar os objetos pessoais dos trabalhadores, tais como bolsas e carteiras, de forma rotineira, ao final do expediente, levando-se em conta as várias correntes doutrinárias que tratam desse assunto. Ressaltou-se a colisão de direitos que este tema propicia, bem como os critérios embasados no princípio da proporcionalidade para a solução desse conflito. Por fim, diante da necessidade de se combater a violência perversa, foram sugeridos métodos de prevenção, numa tentativa de se construir um ambiente de trabalho saudável e equilibrado, em que se valorizem medidas que importem no reconhecimento do trabalhador como um ser humano digno.
\end{abstract}

Palavras-Chave: Assédio moral; Revistas pessoais; Colisão de direitos; Princípio da proporcionalidade; Prevenção.

\section{Introdução}

Os processos de globalização e modernização das relações empresariais provocaram profundas alterações nos postos de trabalho. A inserção de novas leis de mercado, com a imposição de metas e altos índices de produtividade, propiciou a disseminação do fenômeno do assédio moral no cenário das relações empregatícias.

A prática de condutas constrangedoras e vexatórias no ambiente de trabalho, conhecida atualmente pela expressão assédio moral, vem transformando o local de trabalho em um palco de conflitos sem escrúpulos, refletindo, muitas vezes, em situações inusitadas ao direito.

\footnotetext{
${ }^{1}$ Acadêmica do $5^{\circ}$ ano matutino do curso de Direito da Universidade Estadual de Londrina.

${ }^{2}$ Doutor em Direito (PUC-SP); professor associado da Universidade Estadual de Londrina; professor da FACCAR; professor do Curso de Mestrado em Direito da UNIMAR.
} 
Dessa forma, é o procedimento das revistas pessoais, instrumento de fiscalização e controle utilizado rotineiramente pelo empregador nas relações de trabalho, cuja normatização não se encontra consolidada no ordenamento jurídico pátrio, havendo controvérsias doutrinárias a respeito da configuração do assédio moral em razão de tal prática.

Por sua vez, encontra-se nesta questão o foco do presente artigo: a possibilidade de realização das revistas pessoais dos empregados por seus empregadores. 0 empregador, nas atribuições do seu poder diretivo, do seu poder de controle e fiscalização, estaria ofendendo os direitos da personalidade e da dignidade da pessoa humana, tutelados constitucionalmente, ao vasculhar os pertences pessoais dos seus funcionários?

Com a finalidade de solucionar referida questão, faz-se mister apontar a influência da deflagração do assédio moral no contexto das relações empregatícias e até que ponto essa influência atenta contra os princípios fundamentais individuais do trabalhador.

Todavia, mais do que posicionar-se, o presente estudo almeja fornecer métodos preventivos eficazes de combate ao assédio moral, em suas diversas exteriorizações, seja por meio das revistas pessoais, seja através de outras condutas discriminatórias.

\section{Do assédio moral}

Noções conceituais sobre o assédio moral na relação de emprego

Os termos "Assédio Moral", "violência perversa no cotidiano" ou "psicoterror" são expressões utilizadas no Brasil para referir-se a um fenômeno social que pode ser constatado na família, na escola e no ambiente de trabalho.

Tal fenômeno social, também conhecido como Mobbing, nos Países Nórdicos, Suíça e Alemanha; Harassment ou Mobbing, nos Estados Unidos da América; Harcèlement moral, na França; Bullying, na Inglaterra; M arahachibu, no Japão; Acoso moral, na Espanha e Itália, é um mal que assola as sociedades de todo o mundo, haja vista traduzir um processo, conjunto de atos que busca humilhar e constranger a vítima de forma reiterada e prolongada (SILVA, 2005, p. 2).

Ressalta-se que a prática de condutas constrangedoras e vexatórias pode ser encontrada nas relações humanas desde o principiar da história. É o que menciona Cristiane 
Ribeiro da Silva: "o assédio moral trata-se de uma forma de coação que se estabelece em qualquer tipo de relacionamento que se sustente pela desigualdade social ou pelo poder autoritário (2007, p. 83)".

Conforme visto, 0 assédio moral pode ocorrer nas mais variadas relações humanas, podendo ser praticado em qualquer ambiente onde haja uma coletividade. Todavia, é nas relações de trabalho que esse mal social atinge contornos mais dramáticos.

Isto ocorre em virtude da própria estruturação hierárquica do trabalho, marcado pela hipossuficiência de um dos seus sujeitos, pela divisão de tarefas, jornada intensa de labor e responsabilidade excessiva. Neste aspecto, bem enfatiza Rodolfo Pamplona Filho:

$\mathrm{Na}$ relação de trabalho subordinado, porém, este 'cerco' recebe tons mais dramáticos, por força da própria hipossuficiência de um dos seus sujeitos, em que a possibilidade de perda do posto de trabalho que Ihe dá a subsistência faz com que o empregado acabe se submetendo aos mais terríveis caprichos e desvarios, não somente de seu empregador, mas até mesmo de seus próprios colegas de trabalho (2007, p. 193).

Além desses motivos, há outros de suma importância para exímia compreensão da ocorrência do assédio moral, de forma mais comum e agravante, no ambiente de trabalho. Dentre eles destacam-se os processos de globalização e modernização das relações empresarias. Esses processos provocaram alterações nos postos de trabalho, com a conseqüente adoção de procedimentos moralmente reprováveis.

o que se observa, nos ditames atuais, é uma grande preocupação das empresas pela busca do lucro e do poderio econômico. Para tanto, criam-se exigências de metas sem qualquer critério de razoabilidade e bom senso, aflorando o grau de competitividade e de aperfeiçoamento profissional entre os trabalhadores ali inseridos (M OLON, 2006, p. 189).

Tudo isso, de certa forma, contribui para que haja um grande distanciamento entre as pessoas no local de trabalho, um individualismo exacerbado, capaz de desencadear problemas à saúde física e mental do trabalhador, bem como às estruturas da empresa e do Estado.

Vivencia-se, assim, a era da banalização dos sentimentos humanos, produto de um mundo materialista e individualista. Neste contexto econômico-social, as pessoas e, principalmente, os trabalhadores de todo o mundo, passaram a sofrer diversos tipos de violência, com especial destaque para os casos de assédio moral (SILVA, 2005, p. 1). 
É, portanto, em razão da repercussão mundial de seus efeitos e por ser o local de trabalho o mais propício ao desenvolvimento desse tipo de fenômeno social, é que o assédio moral passou a ser analisado, principalmente, sob o prisma laboral. Dentro desse contexto, cumpre apontar os conceitos elaborados pelos estudiosos do assunto, sobre o que seria assédio moral na relação de emprego.

Para o psicólogo alemão Heinz Leymann, o primeiro a debater sobre 0 assunto, 0 fenômeno do assédio moral pode ser conceituado como:

A deliberada degradação das condições de trabalho através do estabelecimento de comunicações não éticas (abusivas), que se caracterizam pela repetição, por longo tempo, de um comportamento hostil de um superior ou colega(s) contra um indivíduo que apresenta, como reação de um quadro de miséria física, psicológica e social duradoura (apud OLIVEIRA, 2004, p. 51).

Baseando-se, ainda, nas inovações e pesquisas trazidas pelo psicólogo alemão, outros importantes e recentes estudos também foram realizados nesta aérea. Destacam-se, assim, as pesquisas realizadas pela vitimóloga francesa M arie-France Hirigoyen, autora de duas importantes obras sobre o tema: "Assédio Moral - A Violência Perversa do Cotidiano" e “M al-Estar no Trabalho - Redefinindo o Assédio M oral” (apud GUEDES, 2004, p. 28).

Marie-France Hirigoyen utiliza as seguintes palavras para definir 0 assédio moral na relação de trabalho:

Toda e qualquer conduta abusiva manifestando-se sobretudo por comportamentos, palavras, atos, gestos, escritos que possam trazer dano à personalidade, à dignidade ou à integridade física ou psíquica de uma pessoa, por em perigo seu emprego ou degradar o ambiente de trabalho (apud PAM PLONA, 2007, p. 194).

No Brasil, esse fenômeno social foi difundido, principalmente, pela dissertação de Mestrado da Médica do Trabalho Margarida Barreto, intitulado "Uma Jornada de Humilhações" (apud GUEDES, 2004, p. 28).

Nos dois conceitos aqui expostos, nota-se que alguns termos são muito freqüentes, quais sejam: humilhação, reiteração da conduta, relação de hierarquia e subordinação, ofensa à personalidade, à dignidade e à integridade física ou psíquica. Tais termos condicionam a uma correta compreensão do instituto do assédio moral, o qual revela na 
palavra "assédio" o sentido de insistência importuna, e, no vocábulo "moral" a ofensa à saúde física e psíquica do trabalhador.

Logo, 0 assédio moral deflagrado na relação de trabalho pode ser compreendido como toda e qualquer conduta abusiva, de natureza psicológica, que expõe o trabalhador a situações humilhantes e constrangedoras, de forma reiterada e prolongada, e que seja capaz de causar ofensa a sua personalidade e dignidade.

\section{Tipos de assédio moral}

\section{Assédio vertical ou descendente}

O assédio vertical ou descendente é aquele praticado entre sujeitos de diferentes níveis hierárquicos, inseridos em uma relação jurídica de subordinação que se sustenta pela desigualdade social ou pelo poder autoritário (PAM PLONA, 2007, p. 195).

Trata-se da modalidade mais comumente admitida de assédio moral e ocorre quando a violência é deflagrada por pessoa que possui ascendência funcional sobre outra, ou seja, quando os subordinados são agredidos pelos empregadores ou superiores hierárquicos.

As razões que desencadeiam a tal perseguição relacionam-se, principalmente, com o medo do superior hierárquico em perder o controle sobre os seus subordinados, bem como com a necessidade de vê-los em uma situação inferior, rebaixando-os para que possa engrandecer-se profissionalmente (M OLON, 2007).

A doutrinadora M artha Halfeld Furtado de M endonça Schmidt demonstra quais são as situações do mundo laboral em que 0 assédio vertical ou descendente pode ser mais facilmente identificado, ao relatar que:

\footnotetext{
0 mobbing descendente pode ser encontrado na situação de um patrão que, não estando satisfeito com um certo empregado, usa de meios para convencê-lo a demitir-se e, conseqüentemente, não ser obrigado a pagar-lhe as verbas decorrentes de uma ruptura por sua iniciativa. Ou então quando um superior hierárquico restringe a autonomia do empregado ou redistribui seu trabalho a outras pessoas (2001, p. 145).
}

Depreende-se, portanto, que este tipo de assédio moral representa uma forma de utilização abusiva dos poderes diretivo e disciplinar conferidos ao empregador e a alguns de 
seus prepostos. Dessa maneira, constata-se que a incidência do assédio moral na relação de trabalho se manifesta, de forma mais freqüente, sob o manto do exercício normal das prerrogativas patronais, que, quando utilizadas de forma abusiva, acabam por deteriorar as condições de trabalho, ferindo frontalmente a saúde física e mental do trabalhador (SCHMIDT, 2001, p. 143).

\section{Assédio horizontal}

0 assédio moral horizontal representa um tipo de perseguição que se propaga entre os próprios colegas de trabalho, ou seja, entre os sujeitos de mesmo nível hierárquico, que não possuem nenhuma relação de subordinação entre si.

Nesta modalidade, a conduta reprovável é geralmente motivada pela competitividade, pela inveja por discrepância salarial, pelo relacionamento privilegiado da vítima com o chefe, por ciúmes, por razões políticas ou religiosas, por maior qualificação profissional do ofendido, por força de preconceito racial e sexual, dentre muitos outros (GUEDES, 2004, p. 38).

Outrossim, a intolerância com o comportamento diferente de alguns colegas de profissão desponta, de igual forma, com um fator ensejador de praticas discriminatórias no ambiente de trabalho. Isto porque a sociedade contemporânea tende a nivelar os seus indivíduos, apresentando dificuldades para lidar com as diferenças (M OLON, 2007).

Frise-se que, além da intolerância pelo diferente, há também as hipóteses atinentes à intolerância racial e étnica. No Brasil, tais hipóteses referem-se, notalvemente, à população do Norte e Nordeste do país, que, em busca de um emprego melhor e de uma vida digna e justa, emigram para a região Sudeste. Todavia, ante a ausência de políticas públicas capazes de propulsionar um desenvolvimento respaldado em justiça social, esses trabalhadores tornam-se os alvos mais freqüentes dos casos de assédio moral por força do racismo e da xenofobia, sofrendo, assim, humilhações que podem advir tanto dos colegas de trabalho, quanto da direção da empresa (GUEDES, 2004, p. 39). 


\section{Assédio vertical ascendente}

Ao contrário do que sucede com o assédio moral do tipo vertical descendente, depara-se aqui com um processo inverso, na qual a violência é perpetuada pelo empregado subordinado em relação ao seu chefe ou empregador.

Assim, quando o hierarquicamente inferior age com o intuito de assediar o seu superior está-se diante de uma violência deflagrada de baixo para cima que, embora de maior raridade, não deixa de ser menos repugnante e prejudicial para as relações laborais.

Nada obstante, teoricamente, as causas mais imediatas deste tipo de manipulação perversa ocorrem quando, por exemplo, um superior recém contratado para assumir a chefia de determinado departamento não consegue atingir um nível de empatia e de adaptação, ou quando, ainda, passa a empregar métodos que são reprovados por seus subalternos (M OLON, 2007).

Nesse sentido, Márcia Novaes Guedes elucida, com propriedade que:

A violência de baixo para cima geralmente ocorre quando um colega é promovido sem a consulta dos demais, ou quando a promoção implica um cargo de chefia cujas funções os subordinados supõem que o promovido não possui méritos para desempenhar (2004, p. 41).

Sem maiores esforços, pode-se cogitar, ainda, do assédio moral ascendente levado a efeito pelo empregado melhor qualificado profissionalmente, que detém os princípios e conhecimentos técnicos inerentes ao processo produtivo. Nesta hipótese, verifica-se a ocorrência de um típico caso de subordinação técnica às avessas, em que o empregador, distante da atividade industrial para dedicar-se exclusivamente à administração da empresa, fica a mercê de seu subordinado, que passa a utilizar de seus conhecimentos como fator impulsionante para a prática do assédio moral (FONSECA, 2007, p. 38).

\section{Assédio moral e revista pessoal}

Partindo-se das considerações supra, tem-se por reproduzido todo o processo de identificação e reconhecimento do assédio moral na relação de trabalho. Contudo, para 
iniciar o questionamento pretendido, a possibilidade de realização das revistas pessoais no local de trabalho, há de ser apresentado algumas particularidades sobre o tema em apreço.

Primeiramente, convém apontar que 0 assédio moral perfaz-se por meio de incontáveis formas, palavras e gestos, na maior parte das vezes dissimulados e circunscrito ao universo do assediante e do assediado. É justamente neste aspecto, ou seja, na constatação de que 0 assédio moral manifesta-se através de condutas que envolvem diversos tipos discriminatórios, que 0 procedimento das revistas pessoais na relação empregatícia passou a ser analisado com maior afinco (BAYEH, 2007).

Assim, ao lado do assédio moral por motivos raciais ou religiosos, do assédio moral em função de deficiência física ou doença, do assédio moral em razão de orientações sexuais, do assédio discriminatório de representantes de funcionários e representantes sindicais, dentre muitos outros, há o assédio moral que se manifesta através da submissão dos empregados ao procedimento das revistas pessoais (AGUIAR, 2007).

Em alguns estabelecimentos empresarias, com destaque para lojas de departamento, em virtude da própria natureza da atividade, como a produção ou comercialização de pequenos componentes elétrico-eletrônicos, roupas íntimas, jóias, alimentos, remédios, substâncias controladas, entre outros, é de praxe que o empregador, amparado pelos poderes de direção, disciplinamento e fiscalização da prestação de serviços, submeta sistematicamente os seus empregados ao procedimento das revistas, após 0 término do expediente.

A fim de resguardar seu patrimônio de eventuais furtos ou desvios de peças, materiais e equipamentos visados pelas atividades ilegais, bem como da introdução de objetos explosivos ou outro capaz de colocar em risco a segurança das pessoas e dos seus bens, o empregador, investido do seu poder de controle e fiscalização, utiliza-se rotineiramente das revistas em seus funcionários, argumentando tratar-se de prerrogativa advinda do poder protetivo do patrimônio empresarial (GÔM ARA; LINHARES NETO, 2008).

No entanto, invariavelmente, alguns procedimentos de revistas extrapolam os limites de atuação diretiva do empregador e atingem a dignidade do ser humano trabalhador.

Embora a ordem jurídica brasileira não determine expressamente quais sejam os limites de atuação diretiva do empregador, ao menos no que concerne ao procedimento das 
revistas íntimas, que pressupõem inspeção direta sobre o corpo do empregado, com a exposição corporal de nudez ou qualquer intimidade, pode-se dizer haver o legislador estabelecido expressamente os limites pelas quais o empregador deve-se pautar quando das atribuições do poder diretivo.

Isto porque o legislador pátrio fez inserir na CLT o artigo 373-A, VI, acrescido pela Lei 9.799 de 1999, que veda o procedimento de revistas íntimas, pelo empregador ou seus prepostos, nas empregadas ou funcionárias. Referida lei, vale dizer, foi elaborada com 0 propósito de proteger apenas a mulher no mercado de trabalho, entretanto, o princípio estampado no artigo 50, I do texto constitucional acabou por proporcionar igualdade no tratamento entre homens e mulheres, estendendo a proteção da intimidade e da dignidade ao trabalhador em geral.

Das considerações retro, infere-se que a revista íntima é aquela que pressupõe inspeção direta sobre o corpo, compreendendo todo ato de molestamento e exposição corporal do funcionário, exigindo que o mesmo se desnude.

A despeito da prática de revistas de natureza íntima, Alice Monteiro de Barros elucida com propriedade singular que:

Considera-se atentatória à intimidade a inspeção que exige que 0 indivíduo se desnude completamente, ainda que perante pessoas do mesmo sexo, e se submeta a exame minucioso, detalhado, prolongado ou em presença de outros. A revista nessas condições encontra limite no respeito à dignidade do trabal hador (2006, p. 562).

Não há dúvidas de que as revistas íntimas são repudiáveis, não se justificando em hipótese alguma, ainda que a vistoria seja respeitosa ou não haja contato físico. A mera exposição do corpo caracteriza grave invasão à intimidade do empregado, em afronta às garantias fundamentais da dignidade da pessoa humana, do valor social do trabalho e da inviolabilidade da intimidade e da honra.

De fato, a CLT, de forma literal, proíbe, em seu artigo 373-A, inciso VI, as empresas de promoverem revistas íntimas em seus funcionários. Indaga-se, porém, se as revistas com averiguação de pertences pessoais devam ser toleradas.

As revistas pessoais, por exclusão das revistas de natureza íntima que implicam em despimento coercitivo, consistem no ato de revistar bolsas, carteiras, papéis, fichários do 
empregado ou espaços a ele reservados, como armários, mesas, escrivaninhas, escaninhos e outros que se tornam privados por destinação.

Apesar da Consolidação das Leis Trabalhistas vedar expressamente o procedimento das revistas íntimas em funcionários, nenhuma disposição consta com relação às demais espécies de revistas, citadas anteriormente. Ao menos neste aspecto específico, a matéria continua sendo objeto de controvérsia.

Em geral, a solução desse impasse fica condicionada à análise minuciosa dos casos concretos pela Justiça brasileira, a qual procura sopesar os contextos que envolvem uma efetiva colisão de direitos: 0 direito do empregador em zelar e salvaguardar o patrimônio empresarial e o respeito à dignidade e à intimidade do trabalhador no seu ambiente de trabalho (GÔM ARA; LINHARES NETO, 2008).

\section{Da colisão de direitos: direito à intimidade do empregado e poder diretivo do empregador}

A questão referente ao procedimento das revistas pessoais do empregado, realizada no local de trabalho pelo empregador ou superior hierárquico, é bastante polêmica, envolvendo não somente aspectos jurídicos, mas também éticos.

Logo, a realização das revistas pessoais na atividade laborativa tem suscitado repercussão na área jurídica, pelo confronto de interesses entre empregado e empregador, situação na qual se verifica uma colisão dos seguintes direitos:

0 direito do empregador de gerir livremente os seus negócios, com fundamento nos princípios constitucionais que legitimam a revista do empregado, em razão da defesa do patrimônio do empregador, como o direito de propriedade (art. 5ํ, XXII da CF) e da livre iniciativa (art. 170 da CF), e o direito do empregado em ter resguardado os seus direitos individuais e fundamentais, inerentes à sua personalidade, como o direito à dignidade, à intimidade, à honra e à vida privada, com fundamento no princípio constitucional de que ninguém será submetido a tratamento desumano ou degradante (art. 50, III da CF) (GÔMARA; LINHARES NETO, 2008).

À colisão de direitos atribui-se o nome de antinomia jurídica, que, para Clèmerson M erlin Clève e Alexandre Reis Siqueira Freire representa: 
Fenômeno que emerge quando o exercício de um direito fundamental por parte de seu titular impede ou embaraça o exercício de outro direito fundamental por parte de outro titular, sendo irrelevante a coincidência entre os direitos envolvidos (2003, p. 232).

Ainda quanto à conceituação de tal fenômeno, Maria Helena de Diniz, de forma exemplar, elucida que colisão de direitos significa "o conflito entre duas normas, dois princípios, ou de uma norma e um princípio geral de direito em sua aplicação prática a um caso particular" (2004, p. 83).

A mesma doutrinadora segue aduzindo que a antinomia será aparente quando os critérios para a solução constituírem normas integrantes do ordenamento jurídico, e real quando não houver na ordem jurídica qualquer critério normativo capaz de solucioná-la, havendo lacuna a ser suprida por eqüidade ou por norma derrogatória de uma das normas conflitantes (DINIZ, 2004, p. 85).

Verifica-se, então, que na hipótese de conflito real há a presença de duas normas conflitantes, sem que se possa saber qual delas deverá ser aplicada ao caso concreto.

Ao debruçar sobre tal temática, o grande constitucionalista português José Joaquim Gomes Canotilho assevera que no confronto entre princípios constitucionais não há antinomia e sim dimensões distintas de concretização, sendo sanáveis pela busca de outros critérios, quais sejam: o juízo de ponderação (ou valores jurídicos fundamentais) e o da dimensão de peso e importância (apud BELM ONTE, 2004, p. 72).

Pelo primeiro critério, o ilustre doutrinador apregoa a regra da máxima observância e da mínima restrição, de maneira que se possa atingir, pelo meio menos lesivo, o menor sacrifício dos direitos em conflito. Já pelo segundo, defende a idéia da mensuração do peso, ou seja, da importância relativa aos interesses em jogo, de modo que se possa optar pela preservação daquele que possua maior valor (CANOTILHO apud BELM ONTE, 2004, p. 72).

Ainda no tocante ao juízo de ponderação, Canotilho condiciona a sua compreensão à análise de três princípios básicos: 0 da unidade da Constituição, consistente na interpretação e harmonização sistemática dos espaços de tensão entre normas de natureza constitucional; o da concordância prática, obtida por meio da coordenação e combinação que permita o melhor equilíbrio possível entre os princípios colidentes, e o da proporcionalidade, que objetiva, por meio do "sopesamento" e estabelecimento de limites, a prevalência de um direito sobre o outro, quando absolutamente imprescindível para a solução do conflito. 


\section{Da posição doutrinária a respeito das revistas pessoais no local de trabalho}

Diante da falta de legislação aplicável à possibilidade de realização das revistas pessoais no ambiente de trabalho, alguns doutrinadores, adentrando nesse estudo arriscam suas posições. Convém transparecer o entendimento de alguns desses profissionais.

Da possibilidade das revistas pessoais

Para os adeptos desta vertente doutrinária, com destaque para Sérgio Pinto M artins e Alice Monteiro de Barros, a prática das revistas pessoais no local de trabalho justifica-se como medida preventiva de segurança, imprescindível à tutela do patrimônio da empresa, destinada a impedir a subtração de bens, matéria-prima, instrumentos de trabalho e produtos pertencentes ao acervo empresarial (BARONIAN, 2007).

Todavia, ressalvam que a realização das revistas pessoais, aceita como prática decorrente do poder diretivo do empregador e como forma de salvaguardar o patrimônio da empresa, não poderá extrapolar o razoável a ponto de caracterizar abuso de direito (M ARTINS, 2004, p. 194).

Logo, para os doutrinadores que compartilham desta posição a legitimidade das revistas pessoais está condicionada à observância de determinados critérios e circunstâncias. 0 primeiro e principal deles é a possibilidade de conciliar o legítimo interesse do empregador na defesa de seu patrimônio, com o indispensável respeito à dignidade e à intimidade do trabalhador no seu posto de trabalho.

Portanto, a revista pessoal deverá ser admitida desde que: seja o último recurso para satisfazer 0 interesse empresarial, ante a ausência de outras medidas de caráter preventivo; existam circunstâncias concretas que permitam a revista, como, por exemplo, os casos em que envolvam alguma contingência temporária para a apuração de fraude, furto, dispensa por justa causa e até, em menor grau, a própria natureza da atividade; seja feita em caráter geral, impessoal e através de critérios objetivos, tais como sorteio e numeração; seja efetuada de forma discreta, em local próprio, reservado, sem a presença de terceiros alheios ao ambiente de trabalho. 
Da impossibilidade das revistas pessoais

Para os que são desfavoráveis a tal prática, valem-se da invocação do direito à privacidade, intimidade, honra e imagem, como direitos absolutos dos trabalhadores, bem como da presunção de confiança que deve nortear as relações laborais. Argumentam que o contrato de trabalho baseia-se no equilíbrio entre as partes e no princípio da confiança mútua. Advertem que se ao empregador remanesce dúvida sobre a integridade moral do candidato ao emprego, deve recusar a contratação, haja vista ser impossível conciliar uma confiança relativa com o contrato de trabalho variável conforme a natureza da atividade da empresa (ZIM M ERM ANN; ABREU, 2007).

Corroborando com este entender, Cássio Luis Casagrande, Procurador do Trabalho, no seu artigo "Direito à Intimidade do Empregado e as Revistas no Local de Trabalho", assevera que:

É preciso ter em mente que o contrato de trabalho tem como um de seus elementos a confiança (fidúcia), e não parece razoável que o empregador lance diariamente uma pecha de dúvida sobre o caráter de seus empregados a pretexto de defender seu patrimônio. Até porque ele jamais o faria em relação a seus clientes ou consumidores, com os quais no mais das vezes não mantém vínculo contratual de confiança (2008).

Dentre os defensores de tal vertente, há de se destacar o posicionamento de Sandra Lia Simón, Procuradora-Geral do Ministério Público do Trabalho.

Para referida autora, não merece prosperar 0 argumento de necessidade das revistas como forma de salvaguardar o patrimônio empresarial, uma vez que as empresas, normalmente, não inspecionam seus clientes e outras pessoas que visitam 0 estabelecimento. Isso não significa que não haja risco de que promovam furtos, já que a probabilidade é sempre maior, mas pelo simples fato de que o cidadão médio consideraria um desrespeito ter a sua privacidade e dignidade submetida à situação tão constrangedora (SÍM ON apud CONTI, 2008).

Nesse particular, Sandra Lia Simón firmou o entendimento de que a esfera particular do indivíduo compreende não apenas o seu corpo, mas também os seus 
pertences, não sendo necessário despir o empregado para que a violação da intimidade ocorra.

Assevera que bolsas, carteiras, pastas e mochilas não são transparentes por um motivo óbvio. Há diversos objetos de uso pessoal que podem causar vergonha, caso sejam desvendados por terceiros. Considerando que apenas a particularidade psicológica de cada ser humano pode afirmar o que the causa constrangimento, não se pode tolerar que sobre a intimidade dos pertences pessoais do obreiro o empregador possa exercer o seu poder diretivo (SÍM ON apud CONTI, 2008).

\section{Dos limites de razoabilidade da revista pessoal}

Conforme exposto, há divergências quanto à possibilidade de realização das revistas pessoais no ambiente laboral. Entretanto, ao contrário da possibilidade de total controle e fiscalização e da vedação ao procedimento da revistas pessoais na relação empregatícia, existe um critério intermediário, em que deva ser estabelecido um padrão razoável de inspeção a ser exercida pelo empregador.

Portanto, nos casos em que surjam conflitos aonde haja direitos fundamentais em questão, como o direito à intimidade, à honra e à imagem do trabalhador e o direito de direção e fiscalização do empregador, deve ponderar-se, mediante a aplicação do princípio da razoabilidade ou da proporcionalidade, como medida de respeito ao direito. Aplicando este princípio será possível conciliar direitos sem que os mesmos tenham o condão de lesionar garantias previstas quando forem confrontados (DUARTE; TUPINAMBÁ, 2002, p. 235).

Visto como uma medida de proteção e como um mecanismo capaz de orientar o Judiciário na arte de fazer justiça, o princípio da proporcionalidade, ao ser invocado, não pode descurar de três critérios, as saber: adequação entre o fim perseguido e 0 instrumento empregado; a necessidade ou exigibilidade da conduta e a proporcionalidade em sentido estrito.

Nesse sentido, realçam-se os dizeres de Canotilho a respeito:

A exigência da adequação aponta para a necessidade de a medida restritiva ser apropriada para a prossecução dos fins invocados pela lei (conformidade com os 
fins); a exigência da necessidade pretende evitar a adoção de medidas restritivas de direitos, liberdades e garantias que, embora adequadas, não são necessárias para se obterem os fins de proteção visados pela Constituição ou lei. Uma medida será então exigível ou necessária quando não for possível escolher outro meio igualmente eficaz, mas menos 'coativo', relativamente aos direitos restringidos; e, finalmente, o princípio da proporcionalidade em sentido estrito (princípio da justa medida) significa que uma lei restritiva, mesmo adequada e necessária, pode ser inconstitucional, quando adote cargas coativas de direitos, liberdades e garantias desmedidas, desajustadas, excessivas ou desproporcionadas em relação aos resultados obtidos (apud CLĖVE; FREIRE, 2003, p. 239).

Direcionando-se os mencionados critérios para o estudo das revistas pessoais nas relações de trabalho, chegar-se-á a solução do impasse que circunda o tema.

Precipuamente, quanto à necessidade de adequação entre o fim perseguido e 0 instrumento empregado, há de se averiguar se as medidas implementadas, quando da adoção das revistas pessoais pelo empregador, são apropriadas. Melhor dizendo, se 0 empregador, com o fim de proteger o seu patrimônio, utiliza-se de métodos adequados ao proceder às revistas rotineiras nos seus funcionários.

Nesse aspecto, cumpre averiguar, conforme bem explicita Alice Monteiro de Barros, se as revistas estão sendo empregadas de forma geral, impessoal, por meio de critérios objetivos, como sorteios, numeração, incluindo todos os que mourejam num mesmo turno ou setor. Ademais, observar-se-á o momento em que deve ser realizada, preferencialmente, ao término do expediente, bem como a existência de um local próprio, reservado, sem a presença de terceiros estranhos, dentro do âmbito empresarial (2006, p. 560).

Ainda assim, diante da comprovação efetiva da empresa quanto à realização da revista pessoal em seus empregados após todas as providências necessárias, torna-se importante observar se as condições de procedibilidade, anteriormente citadas, estão sendo objeto de ajuste em Acordos ou Convenções Coletivas firmadas com o sindicato da categoria, se constam do regulamento da empresa e se há no contrato de trabalho expressa previsão quanto à sua utilização, com a devida ciência do trabalhador (SIM ÕES, 2008).

No que tange ao critério da necessidade ou exigibilidade da conduta, deve-se analisar se, diante do caso concreto e das condições financeiras e estruturais da empresa, 0 empregador possuía outros meios alternativos, menos gravosos, para se chegar ao mesmo resultado, qual seja, a proteção do patrimônio empresarial. 
Diante dos avanços tecnológicos, cada vez mais acessíveis às empresas, convém que sejam explorados meios alternativos. Existem maneiras menos invasivas que podem evitar danos sem ferir garantia fundamental.

Dentro dessa sistemática, a empresa pode valer-se do fornecimento de uniformes para a troca antes do início do expediente e de armários individuais para a guarda de bolsas e de outros pertences pessoais; da instalação de câmeras de vídeo e detectores de objeto; do controle numérico de medicamentos; da readequação do espaço físico; da verificação contábil mais detalhada do estoque, da colocação de etiquetas magnéticas em livros, roupas e remédios; da utilização de senhas, ou até mesmo vigilância feita por serviço especializado ou de chapelaria, dentre outros (GÔM ARA; LINHARES NETO 2008). A preferência, todavia, costuma ser pelo meio mais barato, mas também indignificante.

Por fim, ao adaptar o critério da proporcionalidade em sentido estrito com o objeto ora em apreço, revistas pessoais, levar-se-à em consideração as circunstâncias que as tornam exigíveis e a forma pela qual são realizadas.

Sob esse prisma, as revistas pessoais tornam-se exigíveis e necessárias, sendo adotadas como último recurso, somente em circunstâncias excepcionais, específicas, em que hajas fortes indícios da prática de condutas ilícitas por parte dos funcionários, ou quando a própria natureza da atividade assim determinar.

Todavia, mesmo quando necessárias e adequadas, não poderão ser praticadas em desacordo com os princípios da moralidade e dos bons costumes, respeitando-se ao máximo a esfera da privacidade e da intimidade do trabalhador.

Portanto, havendo circunstâncias justificadoras excepcionais, correlatas à natureza da atividade empresarial e a existência de fortes indícios de condutas ilícitas por parte dos funcionários da empresa, e sendo tal método o único possível na ausência de outros meios tecnológicos menos ofensivos, bem como que seja realizada de maneira adequada, respeitosa e moderada, baseada em critérios objetivos, com previsão expressa no contrato de trabalho e prévia ciência do obreiro, pugna-se pela legitimidade das revistas pessoais no local de trabalho, não tendo, quando atendidos tais parâmetros, que se falar da ocorrência do assédio moral (BUSHATSKY, 2008). 
Resta claro, pelas considerações supra, que a revista é um procedimento legítimo a ser utilizado pelo empregador como meio de proteção de seu patrimônio, e que a maneira como realizada a revista é que definirá a ocorrência ou não do assédio moral.

\section{Da reparação do dano moral}

Em que pese não haver norma jurídica expressa referente ao assédio moral, é evidente, por tudo que se demonstrou no desenrolar do presente estudo, que sua prática ofende 0 princípio norteador de todo o ordenamento pátrio, qual seja, o princípio da dignidade da pessoa humana.

Desta forma, aquele que sofre com a perpetuação do assédio moral poderá pleitear uma indenização civil em razão do dano moral eventualmente sofrido.

Nos dizeres de André Luiz Guedes Fontes "o dano moral é a conseqüência de um ato lesivo que atinge os direitos personalíssimos do indivíduo, os bens de foro íntimo da pessoa, como a honra, a liberdade, a intimidade e a imagem" (2006, p. 16).

De fato, a esfera extra patrimonial dos indivíduos é profundamente violentada com a ocorrência do assédio moral. Em razão disso, a fórmula encontrada pelo ordenamento jurídico para tentar amenizar a dor sofrida pela vítima foi a possibilidade de estipulação de uma compensação, não necessariamente pecuniária, para a reparação do dano de ordem moral (PAM PLONA, 2007, p. 201).

Logo, 0 ato de assédio moral, revelado por meio de condutas que envolvem diversos tipos discriminatórios, dentro os quais se destaca a revista íntima/pessoal, pode levar ao dano moral, desde que comprovados o ato lesivo e o prejuízo decorrente, acarretando a reparação por meio de indenização pecuniária fixada pelo poder Judiciário.

Assim sendo, a reparação civil por danos morais é constantemente invocada quando se fala em assédio moral. Atualmente, com a introdução da Emenda constitucional n. 45/04, a Constituição Federal dispõe, no seu art. 114, inciso VI, que a Justiça do Trabalho é competente para processar e julgar litígios envolvendo a indenização por danos morais que tenham origem na relação de emprego.

Ademais, cumpre registrar que os Tribunais Regionais do Trabalho têm decidido, acerca de processos em que se discute a ocorrência do assédio moral, a imputação aos 
empregadores da obrigação de indenizar seus funcionários pelos danos morais ocasionados a eles. Verifica-se, pois, que no campo da responsabilidade civil, conforme alhures dito, a nova sistemática do direito positivo vigente prevê a responsabilidade objetiva do empregador pelos atos dos seus prepostos, quando do exercício da profissão (SILVA, 2007, p. 87). Trata-se de obrigação que decorre do poder diretivo e da assunção dos riscos do empreendimento.

É o que se infere do julgado:

Dano moral-assédio moral Sofrido Pelo Empregado No Ambiente de TrabalhoConsiderando-se que o empregador assume os riscos da atividade econômica e dirige a prestação pessoal de serviços (art. $2^{\circ}$ da CLT), e considerando-se, ainda, que nosso ordenamento jurídico estabelece que o empregador é responsável pela reparação civil, por atos de seus empregados, no exercício do trabalho que Ihes competir ou em razão dele (art. 932, III, do CC), é inequívoca a responsabilidade do empregador pela reparação patrimonial ao dano sofrido pelo trabalhador que vier a ser submetido ao assédio moral, porquanto a sua culpa pode se configurar até mesmo na sua negligência, que se concretiza pela omissão no controle das atividades desenvolvidas na empresa. Contudo, no presente caso, há de se destacar que, muito embora o reclamante tenha alegado que foi isolado no ambiente de trabalho, o depoimento da única testemunha ouvida nos autos não se mostra suficiente para confirmar 0 assédio moral a que teria sido submetido o reclamante Recurso ordinário não-provido (TRT 15a Região, 3a turma, Processo RO 01251-2002-095-15-00-7, Relator: Desembargador Lorival Ferreira dos Santos. Publicação Data 10.08.2002).

Por fim, ressalva-se que para sanar este grande problema que vem assolando a sociedade e, principalmente, os trabalhadores de todo o mundo, não basta o ressarcimento dos danos morais sofridos, sendo necessário, contudo, que haja a normatização específica em nosso sistema jurídico quanto ao instituto do assédio moral, bem como a conscientização da sociedade, das empresas e do Estado acerca da importância da adoção de medidas preventivas que possibilitem a formação de um ambiente de trabalho sadio e equilibrado.

\section{Da prevenção}

Baseando-se nos relatos das conseqüências vivenciadas pelas vítimas do assédio moral, pesquisadores de todo o mundo, com destaque para os membros do IAP- Instituto de Psicologia e Pedagogia do Trabalho da Alemanha, procuraram sugerir, tanto para as 
empresas, como para os sindicatos e a sociedade, propostas eficazes de combate ao assédio moral, que, se incorporadas poderão trazer excelentes resultados tanto no setor produtivo, como na imagem interna e externa da entidade empresarial (GUEDES, 2004, p. 163).

Alertam, primeiramente, que a construção de um ambiente agradável e psicologicamente saudável ajuda a prevenir o assédio moral, em sua fase inicial. De tal modo que uma reforma na maneira de trabalhar, racionalizando a jornada de labor com atividades que permitam desafogar o estresse, de modo inteligente, podem elidir atitudes hostis e reduzir as chances de aparecimento de conflitos pessoais entre os trabalhadores ali inseridos.

Desse modo, a Comissão Interna de Prevenção de Acidentes, atuando em prol do equilíbrio do meio ambiente laboral, poderá instituir programas de bem-estar e círculos de saúde, que incluam atividades de relaxamento corporal e mental, além de debates sociais relevantes, com músicas e brincadeiras. Tudo isso, de certa forma, exerce influência sobre as condições de trabalho, estimulando a melhoria do relacionamento intergrupal e o crescimento da auto-estima individual de cada um (GUEDES, 2004, p. 163).

Além das mudanças nas condições de trabalho, métodos de prevenção deverão também ser aplicados no comportamento da direção da empresa. 0 ideal seria que, nos treinamentos para gerentes e diretores, se adotassem habilidades para reconhecer 0 conflito na sua fase inicial, solucionando-o da maneira mais rápida e eficaz, de modo a evitar o enraizamento do fenômeno no cenário empregatício.

Todavia, para que os gerentes atuem no combate ao assédio moral, é necessário que haja, na entidade empresarial, um entendimento mútuo de qual comportamento seja aceitável e qual seja imoral. Para resolver esse impasse, imprescindível a elaboração de um código de ética, que, dentre outras previsões, albergue ações preventivas e repressivas contra a perpetuação do assédio moral no ambiente de trabalho (SILVA, 2005, p. 203).

Relativamente aos casos de configuração do assédio moral por meio da prática das revistas pessoais na relação de trabalho, a empresa deverá, conforme outrora suscitado, adequar-se aos novos aparatos tecnológicos alternativos, menos ofensivos, tais como instalação de câmeras de vídeo e detectores de objeto, como mecanismos preventivos da dignidade e da intimidade do obreiro. 
Ademais, uma saída recomendável é que a empresa, juntamente com o sindicato da categoria, firme acordo coletivo de trabalho, fixando as regras a serem observadas quando da adoção do procedimento das revistas pessoais. No entanto, certo é que, mesmo havendo acordo, é possível que os tribunais encontrem motivo para conceder a indenização por danos morais, caso haja comprovação da prática de assédio moral. Por isso, as empresas devem exercer extrema cautela na orientação e supervisão desses atos (SOUZA, 2008).

Deste modo, cabe à empresa, por exemplo, informar aos empregados sobre todo e qualquer procedimento de controle e fiscalização; criar um regulamento ou emitir memorandos e notas claras sobre os procedimentos adotados pela empresa; avisar aos empregados sobre as regras da empresa no momento da contratação e acompanhar todo 0 processo de divulgação da realização das revistas pessoais (BUSHATSKY, 2008).

Ainda, quanto às medidas preventivas, o marketing social representa um poderoso instrumento das organizações sindicais para combater o assédio moral. A comunicação em torno do fenômeno pode ser extremamente importante no processo de conscientização e repressão dessa violência perversa.

Contudo, além das ações preventivas promovidas pelas empresas e pelos sindicatos, a sociedade pode e deve, através de seus líderes políticos, agir no sentido de implementar políticas de educação nos âmbitos escolar e universitário, informando acerca da necessidade de se conhecer e combater 0 assédio moral no ambiente de trabalho (MOLON, 2007).

Diante de todo o exposto, deve-se repensar profundamente 0 ambiente de trabalho, para que seja um ambiente saudável, que possibilite a comunicação, 0 relacionamento, e que se valorizem medidas que importem no engrandecimento do trabalhador como ser humano digno, que sonha, pensa e tem sentimentos.

\section{Conclusão}

Da análise do tema, conclui-se que o assédio moral representa um fenômeno social que pode ocorrer nas mais variadas relações humanas, podendo ser praticado em qualquer ambiente onde haja uma coletividade. Todavia, é nas relações de trabalho que essa violência assume contornos mais dramáticos. 
Conquanto 0 assédio moral exterioriza-se por meio de condutas que envolvem diversos tipos discriminatórios, verificou-se que no procedimento das revistas pessoais, ante a carência de legislação trabalhista à espécie, muito se discute acerca da possibilidade da empresa proceder às inspeções rotineiras em bolsas, carteiras, pastas, mochilas e outros pertences dos seus funcionários, havendo certo receio por parte dos empregadores, tendo em vista, principalmente, as indenizações a que algumas empresas foram condenadas, ao se constatar a ocorrência do assédio moral em virtude de tal prática.

Diante da falta de normatização aplicável à possibilidade de realização das revistas pessoais no ambiente de trabalho e, na tentativa de solucionar uma colisão de direitos, envolvendo de um lado o direito do empregador de gerir livremente os seus negócios, com fundamento no direito de propriedade, e de outro, o direito do empregado em ter resguardado os seus direitos individuais e fundamentais, inerentes à sua personalidade e dignidade, utilizou-se do Princípio da Proporcionalidade, como mecanismo apto a sanar o confronto entre direitos fundamentais.

À luz do princípio da proporcionalidade, procurou-se sopesar os direitos fundamentais e os bens jurídicos em contradição, de modo a proporcionar ao caso concreto solução ajustadora, em que deva ser estabelecido um critério intermediário de inspeção a ser exercida pelo empregador. Para tanto, invocou-se três critérios, a saber: da adequação; da necessidade e o da proporcionalidade em sentido estrito.

Por fim, o presente trabalho sugere às empresas, à sociedade e aos sindicatos medidas preventivas de combate ao assédio moral, seja este deflagrado por meio do procedimento das revistas pessoais, quando realizadas em desacordo com os critérios supramencionados, seja por outros meios discriminatórios.

\section{Referências}

AGUIAR, André Luiz Souza. Assédio moral nas organizações: estudo de caso dos empregados demitidos em litígio judicial trabalhista no Estado da Bahia. Disponível em:

বttp://www.anicleide.com.br/art4assediomoral.pdf>. Acesso em: 06 set. 2007.

BARONIAN, Roberto. 0 poder diretivo do empregador e a revista pessoal. Disponível em: বhttp://ultimainstancia.uol.com.br/artigos/ler_noticia. php?idNoticia $=40935>$. Acesso em: 06 set. 2007. 
BAYEH, Sharkis Joud. 0 professor e 0 assédio moral. Revista PUCViva, n. 22. Disponível em: বhttp://www.apropucsp.org.br/revista/r22_r02.htm>. Acesso em: 06 set. 2007.

BELM ONTE, Alexandre Agra. 0 monitoramento da correspondência eletrônica nas relações de trabalho. São Paulo: LTr, 2004.

BUSHATSKY, Sérgio. Hora de checar: se não expõe funcionário, revista não gera dano moral. Disponível em: \ttp://conjur.estadao.com.br/static/text/57838,1>. Acesso em: 04 maio 2008.

CASAGRANDE, Cássio Luís. 0 direito à intimidade do empregado e as revistas no local de trabalho. Disponível em: ঝttp://www.pgt.mpt.gov.br/pgtgc/ >. Acesso em: 15 maio 2008.

CONTI, Adriana. M esa científica aborda pontos polêmicos sobre a invasão da privacidade do trabalhador. Disponível em: «ttp://www.pgt.mpt.gov.br/pgtgc>. Acesso em: 15 maio 2008.

CLĖVE, Clèmerson Merlin; FREIRE, Alexandre Reis Siqueira. Algumas Notas sobre Colisão de Direitos Fundamentais. In: GRAU, Eros Roberto; CUNHA, Sérgio Sérvulo da (Coord.). Estudos de direito constitucional em homenagem a José Afonso da Silva. São Paulo: Malheiros, 2003.

DINIZ, Maria Helena. Curso de Direito Civil Brasileiro. v. 1: Teoria Geral do Direito Civil. 21. ed. ver de acordo com o novo Código Civil. São Paulo: Saraiva, 2004.

DUARTE, Juliana Bracks; TUPINAM BÁ, Carolina. Direito à intimidade do empregado x direito de propriedade e poder diretivo do empregador. Revista de Direito do Trabalho, São Paulo, v. 28, n. 105, p. 235, jan./mar 2002.

FONSECA, Rodrigo Dias da. Assédio moral: breves notas. Revista LTr, São Paulo, v. 71, n. 1, p. 38, jan. 2007.

FONTES, André Luiz Guedes. Assédio moral no contrato de emprego. Revista IOB, Porto Alegre, n. 208, p. 16, out. 2006.

GÔM ARA, M arcelo Pereira; LINHARES NETO, M eire Chrystian. A prática da revista física do trabalhador. Disponível em:

«ttp://www.sindicatomercosul.com.br/noticia02.asp?noticia=28001>. Acesso em: 07 maio 2008.

GUEDES, M árcia Novaes. Terror psicológico no trabalho. 2. ed. São Paulo: LTr, 2004.

M ARTINS, Sérgio Pinto. Direito do trabalho. 20. ed. São Paulo: Atlas, 2004.

M OLON, Rodrigo Cristiano. Assédio moral no ambiente de trabalho e a responsabilidade civil: empregado e empregador. Disponível em:

বhttp://jus2.uol.com.br/doutrina/texto.asp?id=6173>. Acesso em: 06 set. 2007.

Revista de DiReito Púbuico, LondRINA, V. 3, N. 3, P. 104-126, SET./ DeZ. 2008. 
. Assédio moral no trabalho e suas implicações no futuro do direito do trabalho. Revista do Direito do Trabalho e Ambiente, Rio Grande do Sul, v. 4, n. 6, p. 189, jan./jun. 2006.

OLIVEIRA, Euler Sinoir. Assédio moral: sujeitos, danos à saúde e legislação. Revista de Direito do Trabalho, São Paulo, v. 30, n. 114, p. 51, abr./jun. 2004.

PAM PLONA FILHO, Rodolfo. Noções conceituais sobre 0 assédio moral na relação de emprego. Revista de Direito do Trabalho, São Paulo, ano 33, n. 125, p. 193-201, jan./mar. 2007

SCHM IDT, M artha Halfeld Furtado de M endonça. 0 assédio moral no direito do trabalho. Revista de Direito do Trabalho, São Paulo, v. 27, n. 103, p. 143-145, jul./ set. 2001.

SILVA, Cristiane Ribeiro da. Assédio moral no ambiente de trabalho e a responsabilidade civil do empregador. Revista IOB, Porto Alegre, v. 17, n. 211, p. 83, jan. 2007.

SILVA, Jorge Luiz de Oliveira da. Assédio moral no ambiente de trabalho. Rio de Janeiro: Editora e Livraria Jurídica do Rio de Janeiro, 2005.

SIM ÕES, Crislaine. A revista de funcionários em empresas é legal?. Disponível em: বhttp://www.innocenti.com.br/materia.aspx?id=72>. Acesso em: 04 abr. 2008.

SOUZA, Ana Paula Simone de Oliveira. Revista íntima e danos morais. Disponível em: «ttp://www.amatra4.org.br/Comunicacao/Artigos/1727>. Acesso em: 07 abr. 2008.

ZIM M ERM ANN, Deyse Jacqueline; ABREU, Lílian Leonor. Direito à intimidade x revista pessoal do empregado. Disponível em: «ttp://www.saraivajur.com.br/doutrinaArtigosDetalhe.cfm?doutrina=739>. Acesso em: 06 set. 2007. 